\title{
The influence of digital customer experience and electronic word of mouth on brand image and supply chain sustainable performance
}

\author{
Leonardus W Wasono Mihardjo ${ }^{a^{*}}$, Sasmoko $^{\mathrm{b}}$, Firdaus Alamsjah ${ }^{\mathrm{b}}$ and Elidjen $^{\mathrm{b}}$
}

${ }^{a}$ Doctor of Research in Management Program, Business School, Bina Nusantara University, Jl. Hang Lekir I, No.6. Jakarta Pusat, Indonesia ${ }^{b}$ Business School, Bina Nusantara University, Jl. Kebon Jeruk Raya No.27, West Jakarta, Indonesia

\section{H R O N I C L E}

\begin{tabular}{l}
\hline Article history: \\
Received March 1, 2019 \\
Received in revised format April \\
1,2019 \\
Accepted April 42019 \\
Available online \\
April 5 2019 \\
\hline Keywords: \\
Digitalization \\
e-commerce \\
Brand image \\
Supply chain \\
Sustainable performance
\end{tabular}

\section{Introduction}

Digitalization plays crucial role in the current competitive market (Leetaru, 2008). Most of the business markets heavily depend on digitalization and it is one of the most essential elements of business market. Digitalization is the utilization of digital technologies to change a business model and to deliver new value-producing opportunities to the current business environment; it is also a procedure for moving towards a digital business. Basically, it is the way of new innovation in business model. Introduction of new technology for the sake of digitalization brings innovativeness to the business activities which makes faster transections and physical transfer of goods. Therefore, it also has the effect on supply chain activities. Generally, supply chain digitalization comes under electronic supply chain (e-supply chain) (Poirier \& Bauer, 2000). Digitalization facilitates supply chain activities of business (Castorena et al., 2014; Dim \& Ezeabasili, 2015; Wang \& Lu, 2016; Vendrell-Herrero et al., 2017).

\footnotetext{
* Corresponding author

E-mail address: mihardjo@gmail.com (L.W.W. Mihardjo)

C 2019 by the authors; licensee Growing Science.

doi: $10.5267 /$ j.uscm.2019.4.001
} 
Supply chain has central importance for every business activity (Peng et al., 2016; Quarshie et al., 2016; Richter \& Walther, 2016). These activities play crucial role in customer satisfaction (Duru \& Chibo, 2014; Purnama, 2014; Nazal, 2017; Taqi et al., 2018; Nadeem et al., 2018) which may have significant effects on sustainable business outcomes. In this competitive environment, companies are moving towards higher performance of supply chain activities. Higher performance of supply chain activities depends on digitalization. Therefore, digitalization is one of the important elements of supply chain. However, firms experience important risk when they implement digital supply chain arrangements to manage the collaboration with their partners (Xue et al., 2013). Generally, digitalization is based on electronic commerce (Chaudhuri \& Mukhopadhyay, 2014; Nauwelaerts \& Chakri, 2016; Tanoos, 2017; Chowdhury et al., 2018) which is expensive to develop. These companies experience financial constraints to adopt digitalization in supply chain activities. Companies also face various technological issues related to digitalization.

Digitalization plays an important role on creating good words of mouth. Digital customer experience has significant effect on customer satisfaction (Joshi, 2018) by providing better customer value (Bolton et al., 2018; Klaus, 2014). It provides better experience for customers through digitalization (Betzing et al., 2018) which influence on brand image, significantly. It also creates positive word-of-mouth among customers having significant effect on supply chain since better customer experience always has positive effect on business activities (Merrilees, 2016). Both the customer digital experience and word of mouth influence on brand image, positively. Better brand image always shows positive effect on supply chain image. As the brand and supply chain play important role on each other's (Brun \& Castelli, 2008; Nze et al., 2016; Kimengsi \& Gwan, 2017; Cheng et al., 2018 ; CHE \& Sundjo, 2018).

Brand image and supply chain image play important role on the performance of sustainable supply chain since the brand image has relationship with supply chain (Kim \& Cavusgil, 2009) which is the key to the sustainable business performance. Thus, the objective of this study is to explore the effect of digital customer experience and electronic word of mouth on the performance of the sustainable supply chain through brand image and supply chain image. The relationship between digital customer experience, electronic word of mouth, brand image, supply chain image and supply chain sustainable performance are shown in Fig. 1.

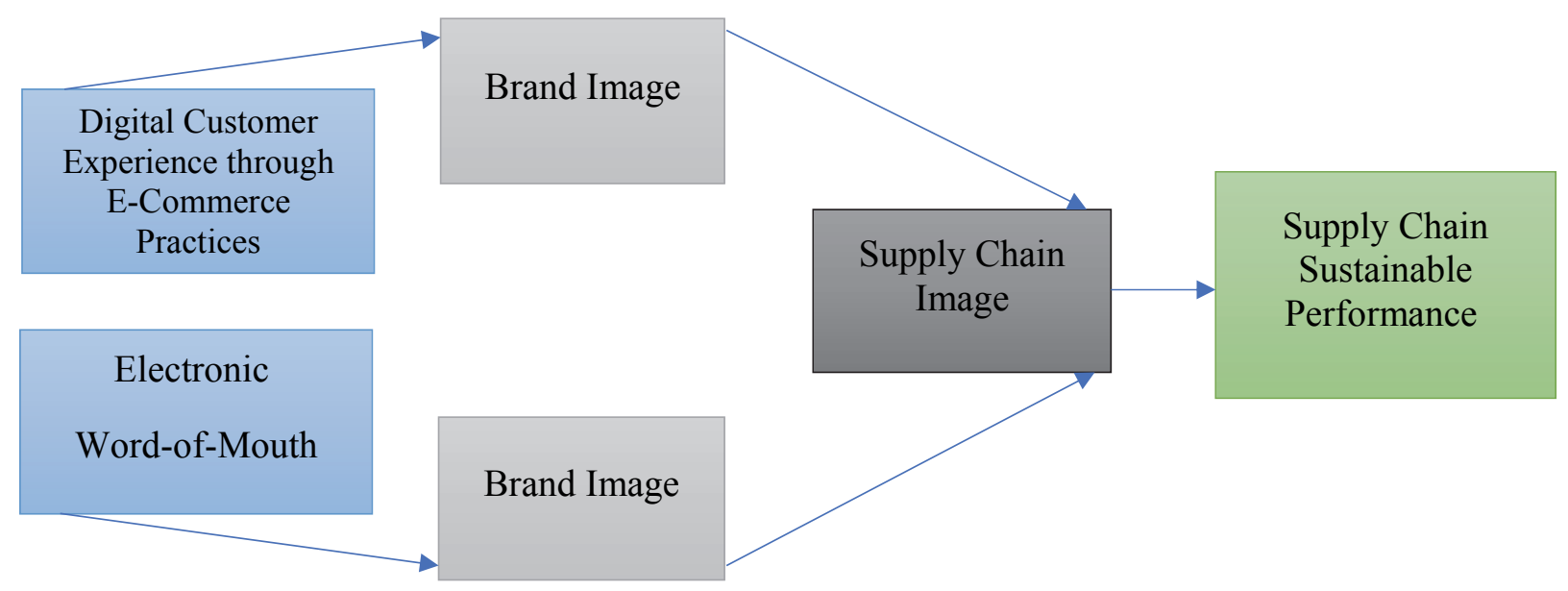

Fig. 1. Theoretical framework of the study showing the relationship between digital customer experience, electronic word of mouth, brand image, supply chain image and supply chain sustainable performance

This study has special focus on Indonesian Information and Communication and Technology (ICT) companies. ICT companies are important for any economies (Pradhan et al., 2018) and they contribute on gross domestic product, significantly. However, these companies are facing problems due to rapid changes in digital technology (Cloud service) and lack of infrastructure for ICT (Das et al., 2016). 
Supply chain in ICT plays an important role for growth of the companies, thus, for better performance, these companies need to have sustainable supply chain performance.

\section{Theoretical Outlook and Hypotheses Development}

Electronic commerce (e-commerce) has changed over the last 30 years. Initially, e-commerce was associated with the enablement of various commercial transactions through digital communication (Gebrina, 2009). In 1970s, organizations started to send commercial electronic documents like various purchase orders through electronic methods. The growth as well as the acceptance of various credit cards, PayPal services, automated teller machines (ATM) and online telephone banking in the 1980s were considered as various forms of e-commerce. Online shopping was developed in the United Kingdom (Aldrich, 1979). From onwards 1990s, e-commerce simply means enterprise resource preparation, data mining as well as data warehousing (Reynolds \& Mofazali, 2000).

The idea of E-commerce is involved with the formation of a suitable infrastructure which would facilitate the essential functionality. Such infrastructure must play two main roles. It should help the businesses exploit the total number of customers. The internet also helps suppliers communicate directly with buyers (marketing by developing the profile of customers) and in the future it will be the fruitful expansion of individual links with customers that will decide the e-enterprise' achievement (Galant et al., 2002). This whole process requires good technology in which industry 4.0 plays an important role in the recent decades (Imran et al., 2018).

The idea of electronic commerce (e-commerce) raised up in the dynamism of information, technology and communication era. Though, the quick increase of the internet has completed the likelihood of the e-commerce more promising. It is now extensively specified that the internet as well as e-commerce would change traditional business and consumer life (Männistö, 1999). E-commerce has an important relationship with brands. It has the ability to create a good brand image. The customers having good digital experience through e-commerce have good views about the brand.

As it is found by various studies that branding and e-commerce has link with each other (Lowry et al., 2008; Penttinen \& Turunen, 2017). E-commerce influences positively on branding and provides the access to brand and help to popularity of brand in no time. Better access to the brand and popularity of brand creates a good image in the market and among the customers which has the ability to boost supply chain for the related products. It provides electronic business solution to facilitates performance (Davis \& Vladica, 2005) and develops a good brand image among customers. It is proved by various studies that brand has significant link with e-commerce activities and customers' digital experience (Bilgihan, 2016; Morgan-Thomas \& Veloutsou, 2013; Nguyen, 2001; Strebinger \& Treiblmaier, 2006).

$\mathbf{H}_{1}$ : Digital customer experience through e-commerce practices has positive effect on brand image.

Consistent with digital customer experience, electronic word of mouth also has similar effect on brand image. Word of mouth is the procedure of transmission information from one person to another and plays an important role in customer decisions process associated with the purchase decisions (Richins \& Root-Shaffer, 1988). In commercial conditions, word of mouth includes consumers sharing attitudes, views, or reactions related to businesses services and products with various people. Word of mouth marketing is powerful, multi-layered, and classically hard to effect (Dellarocas, 2003; Ha, 2002; Phelps et al., 2004). Positive word of mouth is measured by an influential marketing medium for organizations to influence consumers. Functions of word of mouth communication grounded on social interacting as well as trust: people trust on friends, relatives and others in their social network. It is proved that people seem to trust apparently unbiased opinions from people outside their instant social network, such as online reviews (Duan et al., 2008). This form is known as online word of mouth or electronic word of mouth which is heavily based on e-commerce. 
Positive electronic word of mouth has significant effect on brand image. Word of mouth is ranked the most important information cause when various consumers are doing a purchase decision (Litvin et al., 2008) which shows positive influence on brand image. With the help of Web-based consumer opinion platforms, the internet allows clients to share their views, ideas, thoughts and experiences regarding goods as well as services with a gathering of other consumers which effect positively (Hennig-Thurau et al., 2004). Therefore, positive word of mouth has significant role on creating awareness about a specific product among the general public. Electronic word of mouth creates good brand image through e-commerce practices. It ultimately influences on the performance of specific product by increasing the sales of particular product. Increase in the sales of product automatically boosts supply chain activities which influences positively on supply chain activities and sustainable supply chain performance among companies.

$\mathbf{H}_{2}$ : Electronic word of mouth has positive effect on brand image.

In a similar way, both digital customers experience through e-commerce and electronic word of mouth has positive role to boost brand image, brad image has positive role to boost supply chain image among

ICT industry. Good brand image leads towards better supply chain image which ultimately has positive effect on sustainable supply chain performance. Branding has also relationship with supply chain image (Czinkota et al., 2014; Farquhar, 1994; Tsou et al., 2009; Zhang et al., 2013, Mihardjo et al., 2018). Thus, literature provides some significant evidence that branding has important relationship with supply chain activities.

Good supply chain image leads towards sustainable supply chain performance. Better supply chain activities sustain the supply chain performance (Attaran \& Attaran, 2007; De Brito et al., 2008; Golicic $\&$ Smith, 2013) which increases the customer satisfaction level (Nadeem et al., 2018). Increase in sustainable performance increases the overall performance of ICT companies. Here the information technology plays a key role to develop connection between digital customer experience, word of mouth, brand image, supply chain image and supply chain sustainable performance. Therefore, literature provides the importance of brand image, supply chain image and supply chain performance which means that brand image has relationship with supply chain image and increases the sustainable performance related to supply chain. By following the instructions of Baron and Kenny (1986), these findings from the literature reveals that brand image mediates the relationship between digital customer experience through e-commerce practices and supply chain image. Moreover, it is revealed that brand image mediates the relationship between digital word of mouth and supply chain image.

H3- Brand image has positive effect on supply chain image.

H4- Supply chain image has positive effect on sustainable supply chain performance.

H5- Brand image mediates the relationship between digital customer experience through e-commerce practices and supply chain image.

H6- Brand image mediates the relationship between digital word of mouth and supply chain image.

H7- Supply chain image mediates the relationship between brand image and sustainable supply chain performance.

\section{Data Collection Procedure and Analysis Method}

In this study, data is collected from employee of ICT companies. The employees involved in distribution of the company products were selected to collect the responses since these employees were involved in supply chain activities. The data collection of this study is based on three major steps. Moreover, the process of data collection was majorly based on three key steps; 
1. Indonesia was divided into 15 clusters.

2. 10 clusters were selected randomly.

3. Respondents were selected randomly from ICT companies.

According to Krejcie and Morgan (1970), 382 sample size is sufficient if the population is 100,000. By following the instructions, the current study selected 568 sample size. Total of 568 questionnaires were distributed. All the questionnaires were distributed with the help of self-visit to the ICT companies. From these 568 questionnaires, 315 valid responses were returned and used for data analysis. Collected data were analysed with the help of structural equation modelling (SEM) and by using partial least square (PLS). It is recommended in literature by different researchers (Hair et al., 2017; Hair Jr et al., 2016; Henseler et al., 2009).

\section{Results}

Results of this study are analysed by using partial least square and, first, missing values, outliers and normality of the data were examined and it is found that data were free from missing values and any case of outlier. In case of normality, partial least square (PLS) is the most suitable to analyse the data which is not normal (Hair Jr et al., 2016). Missing values, outliers and normality of the data are shown in Table 1.

Table 1

Missing Value, Outlier and Normality of the Data

\begin{tabular}{lccccccccc}
\hline & No. & Missing & Mean & Median & Min & Max & SD & Kurtosis & Skewness \\
\hline DCE1 & 1 & 0 & 3.275 & 3 & 1 & 7 & 1.51 & -0.465 & 0.102 \\
DCE2 & 2 & 0 & 3.234 & 3 & 1 & 7 & 1.783 & -0.579 & 0.444 \\
DCE3 & 3 & 0 & 3.523 & 3 & 1 & 7 & 1.859 & -0.783 & 0.311 \\
DCE4 & 4 & 0 & 3.482 & 3 & 1 & 7 & 1.902 & -0.81 & 0.392 \\
DCE5 & 5 & 0 & 3.527 & 3 & 1 & 7 & 1.689 & -0.443 & 0.295 \\
DCE6 & 6 & 0 & 3.491 & 4 & 1 & 7 & 1.8 & -0.723 & 0.239 \\
EWOM1 & 7 & 0 & 3.45 & 4 & 1 & 7 & 1.807 & -0.934 & 0.12 \\
EWOM2 & 8 & 0 & 3.653 & 4 & 1 & 7 & 1.858 & -0.793 & 0.206 \\
EWOM3 & 9 & 0 & 3.707 & 3 & 1 & 7 & 1.853 & -0.755 & 0.319 \\
EWOM4 & 10 & 0 & 3.631 & 3 & 1 & 7 & 1.912 & -0.738 & 0.382 \\
EWOM5 & 11 & 0 & 3.541 & 3 & 1 & 7 & 1.871 & -0.715 & 0.379 \\
EWOM6 & 12 & 0 & 3.55 & 3 & 1 & 7 & 1.807 & -0.552 & 0.364 \\
BI1 & 13 & 0 & 3.581 & 3 & 1 & 7 & 1.882 & -0.779 & 0.306 \\
BI2 & 14 & 0 & 3.482 & 3 & 1 & 7 & 1.757 & -0.434 & 0.454 \\
BI3 & 15 & 0 & 3.527 & 4 & 1 & 7 & 1.909 & -0.94 & 0.206 \\
BI4 & 16 & 0 & 3.468 & 3 & 1 & 7 & 1.795 & -0.609 & 0.325 \\
SCI1 & 17 & 0 & 3.658 & 4 & 1 & 7 & 1.786 & -0.667 & 0.253 \\
SCI2 & 18 & 0 & 3.09 & 3 & 1 & 7 & 1.483 & -0.133 & 0.578 \\
SCI3 & 19 & 0 & 3.176 & 3 & 1 & 7 & 1.513 & 0.418 & 0.877 \\
SCI4 & 20 & 0 & 3.23 & 3 & 1 & 7 & 1.451 & 0.759 & 0.912 \\
SCSP1 & 21 & 0 & 3.144 & 3 & 1 & 7 & 1.473 & 0.384 & 0.746 \\
SCSP2 & 22 & 0 & 3.113 & 3 & 1 & 7 & 1.398 & 0.481 & 0.663 \\
SCSP3 & 23 & 0 & 3.194 & 3 & 1 & 7 & 1.52 & 0.275 & 0.7 \\
SCSP4 & 24 & 0 & 3.144 & 3 & 1 & 7 & 1.469 & 0.493 & 0.812 \\
SCSP5 & 25 & 0 & 3.032 & 3 & 1 & 7 & 1.434 & -0.286 & 0.424 \\
SCSP6 & 26 & 0 & 3.189 & 3 & 1 & 7 & 1.389 & 0.318 & 0.612 \\
\hline & & & & & & & & & \\
\hline
\end{tabular}

Fig. 2 shows the first step of PLS-SEM; measurement model. In this step, factor loadings were examined shown in Table 2. All the items have maintained factor loadings of above 0.7 and composite reliability (CR) is also above 0.7 . Average variance extracted (AVE) above 0.5 confirms the convergent validity. AVE and CR are shown in Table 3. 


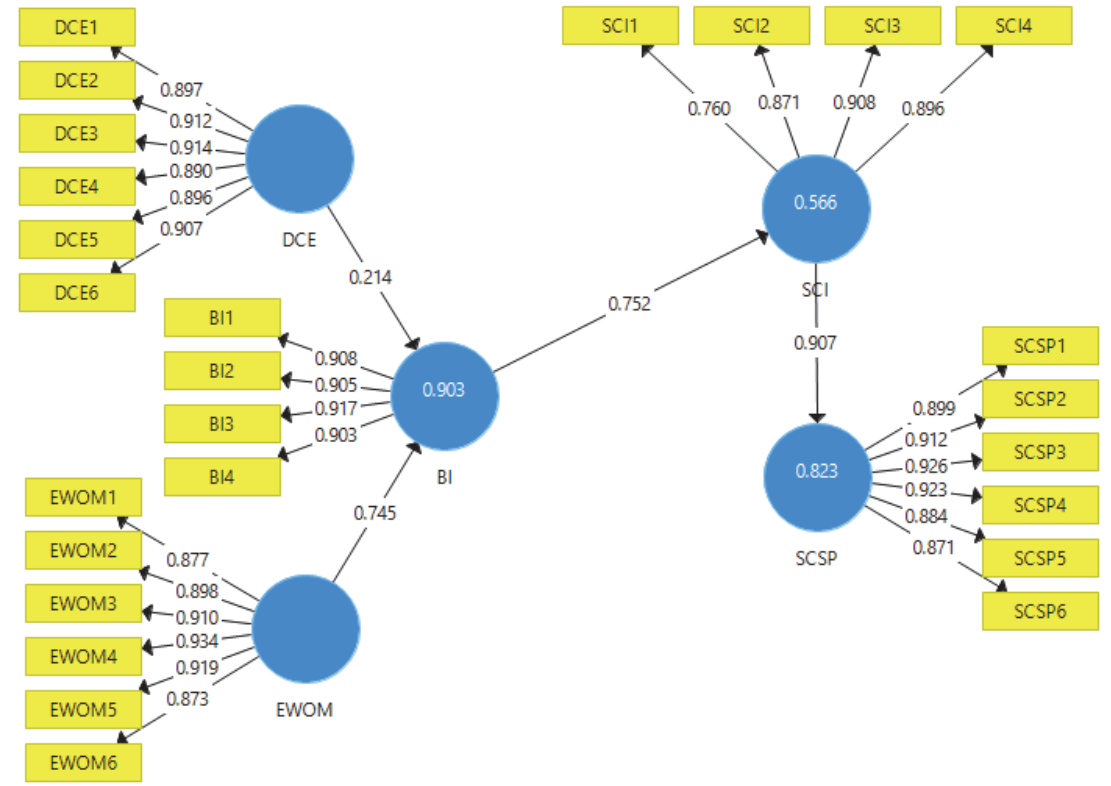

Fig. 2. Measurement Model Assessment

Table 2

Factor Loadings

\begin{tabular}{|c|c|c|c|c|c|}
\hline & BI & $\mathrm{DCE}$ & EWOM & $\mathrm{SCI}$ & SCSP \\
\hline BI1 & 0.908 & & & & \\
\hline BI2 & 0.905 & & & & \\
\hline BI3 & 0.917 & & & & \\
\hline BI4 & 0.903 & & & & \\
\hline DCE1 & & 0.897 & & & \\
\hline DCE2 & & 0.912 & & & \\
\hline DCE3 & & 0.914 & & & \\
\hline DCE4 & & 0.89 & & & \\
\hline DCE5 & & 0.896 & & & \\
\hline DCE6 & & 0.907 & & & \\
\hline EWOM1 & & & 0.877 & & \\
\hline EWOM2 & & & 0.898 & & \\
\hline EWOM3 & & & 0.91 & & \\
\hline EWOM4 & & & 0.934 & & \\
\hline EWOM5 & & & 0.919 & & \\
\hline EWOM6 & & & 0.873 & & \\
\hline SCI1 & & & & 0.76 & \\
\hline SCI2 & & & & 0.871 & \\
\hline $\mathrm{SCI} 3$ & & & & 0.908 & \\
\hline SCI4 & & & & 0.896 & \\
\hline SCSP1 & & & & & 0.899 \\
\hline SCSP2 & & & & & 0.912 \\
\hline SCSP3 & & & & & 0.926 \\
\hline SCSP4 & & & & & 0.923 \\
\hline SCSP5 & & & & & 0.884 \\
\hline SCSP6 & & & & & 0.871 \\
\hline
\end{tabular}

\section{Table 3}

Reliability and Convergent Validity

\begin{tabular}{lllll}
\hline & $\alpha$ & rho A & CR & $($ AVE) \\
\hline BI & 0.929 & 0.93 & 0.95 & 0.825 \\
DCE & 0.954 & 0.955 & 0.963 & 0.815 \\
EWOM & 0.954 & 0.955 & 0.963 & 0.814 \\
SCI & 0.881 & 0.882 & 0.919 & 0.741 \\
SCSP & 0.954 & 0.955 & 0.963 & 0.815 \\
\hline
\end{tabular}


In PLS structural equation modelling, there are three methods to determine discriminant validity. This study selected cross loadings to examine discriminant validity. It is shown in Table 4 which confirms the discriminant validity. Moreover, as discussed earlier, convergent validity is confirmed through AVE.

\section{Table 4}

Cross Loadings

\begin{tabular}{|c|c|c|c|c|c|}
\hline & BI & DCE & EWOM & SCI & SCSP \\
\hline BI1 & 0.908 & 0.83 & 0.863 & 0.66 & 0.558 \\
\hline BI2 & 0.905 & 0.819 & 0.849 & 0.657 & 0.547 \\
\hline $\mathrm{BI} 3$ & 0.917 & 0.865 & 0.889 & 0.697 & 0.615 \\
\hline BI4 & 0.903 & 0.826 & 0.841 & 0.718 & 0.608 \\
\hline DCE1 & 0.832 & 0.897 & 0.844 & 0.738 & 0.694 \\
\hline DCE2 & 0.838 & 0.912 & 0.852 & 0.674 & 0.606 \\
\hline DCE3 & 0.831 & 0.914 & 0.858 & 0.684 & 0.601 \\
\hline DCE4 & 0.821 & 0.89 & 0.85 & 0.731 & 0.668 \\
\hline DCE5 & 0.832 & 0.896 & 0.858 & 0.743 & 0.659 \\
\hline DCE6 & 0.826 & 0.907 & 0.869 & 0.715 & 0.648 \\
\hline EWOM1 & 0.832 & 0.87 & 0.877 & 0.713 & 0.631 \\
\hline EWOM2 & 0.843 & 0.856 & 0.898 & 0.671 & 0.591 \\
\hline EWOM3 & 0.888 & 0.848 & 0.91 & 0.7 & 0.617 \\
\hline EWOM4 & 0.868 & 0.872 & 0.934 & 0.711 & 0.614 \\
\hline EWOM5 & 0.864 & 0.855 & 0.919 & 0.69 & 0.621 \\
\hline EWOM6 & 0.831 & 0.828 & 0.873 & 0.695 & 0.609 \\
\hline SCI1 & 0.749 & 0.714 & 0.722 & 0.76 & 0.603 \\
\hline $\mathrm{SCI} 2$ & 0.57 & 0.613 & 0.603 & 0.871 & 0.818 \\
\hline SCI3 & 0.603 & 0.663 & 0.629 & 0.908 & 0.844 \\
\hline SCI4 & 0.563 & 0.628 & 0.6 & 0.896 & 0.85 \\
\hline SCSP1 & 0.567 & 0.634 & 0.604 & 0.831 & 0.899 \\
\hline SCSP2 & 0.605 & 0.66 & 0.647 & 0.815 & 0.912 \\
\hline SCSP3 & 0.575 & 0.643 & 0.606 & 0.818 & 0.926 \\
\hline SCSP4 & 0.6 & 0.69 & 0.644 & 0.845 & 0.923 \\
\hline SCSP5 & 0.593 & 0.657 & 0.606 & 0.811 & 0.884 \\
\hline SCSP6 & 0.531 & 0.59 & 0.576 & 0.792 & 0.871 \\
\hline
\end{tabular}

The hypotheses developed in literature review were tested by using PLS bootstrapping techniques which is one of the suitable techniques in SEM. Fig. 3 shows PLS structural model and Table 5 and Table 6 show the results of PLS structural model. It is found that all the relationships have t-values above 1.96 which confirm the relationships. Moreover, all the mediation effect also has t-value above 1.96 which confirms mediation effect. Thus, these results supported all seven hypotheses.

Table 5

Direct Effect Results

\begin{tabular}{llllll}
\hline & $(\beta)$ & $(\mathrm{M})$ & SD & T Statistics & P Values \\
\hline $\mathrm{BI} \rightarrow$ SCI & 0.752 & 0.75 & 0.03 & 25.167 & 0 \\
$\mathrm{DCE} \rightarrow$ BI & 0.214 & 0.214 & 0.069 & 3.086 & 0.002 \\
EWOM $\rightarrow$ BI & 0.745 & 0.745 & 0.067 & 11.084 & 0 \\
SCI $\rightarrow$ SCSP & 0.907 & 0.907 & 0.011 & 84.298 & 0 \\
\hline
\end{tabular}

Table 6

In-Direct Effect Results

\begin{tabular}{llllll}
\hline & $(\beta)$ & $(\mathrm{M})$ & SD & T Statistics & P Values \\
\hline $\mathrm{DCE} \rightarrow \mathrm{BI} \rightarrow$ SCI & 0.161 & 0.161 & 0.053 & 3.059 & 0.002 \\
$\mathrm{EWOM} \rightarrow$ BI $\rightarrow$ SCI & 0.56 & 0.559 & 0.055 & 10.274 & 0 \\
$\mathrm{BI} \rightarrow \mathrm{SCI} \rightarrow$ SCSP & 0.682 & 0.681 & 0.03 & 22.993 & 0 \\
\hline
\end{tabular}




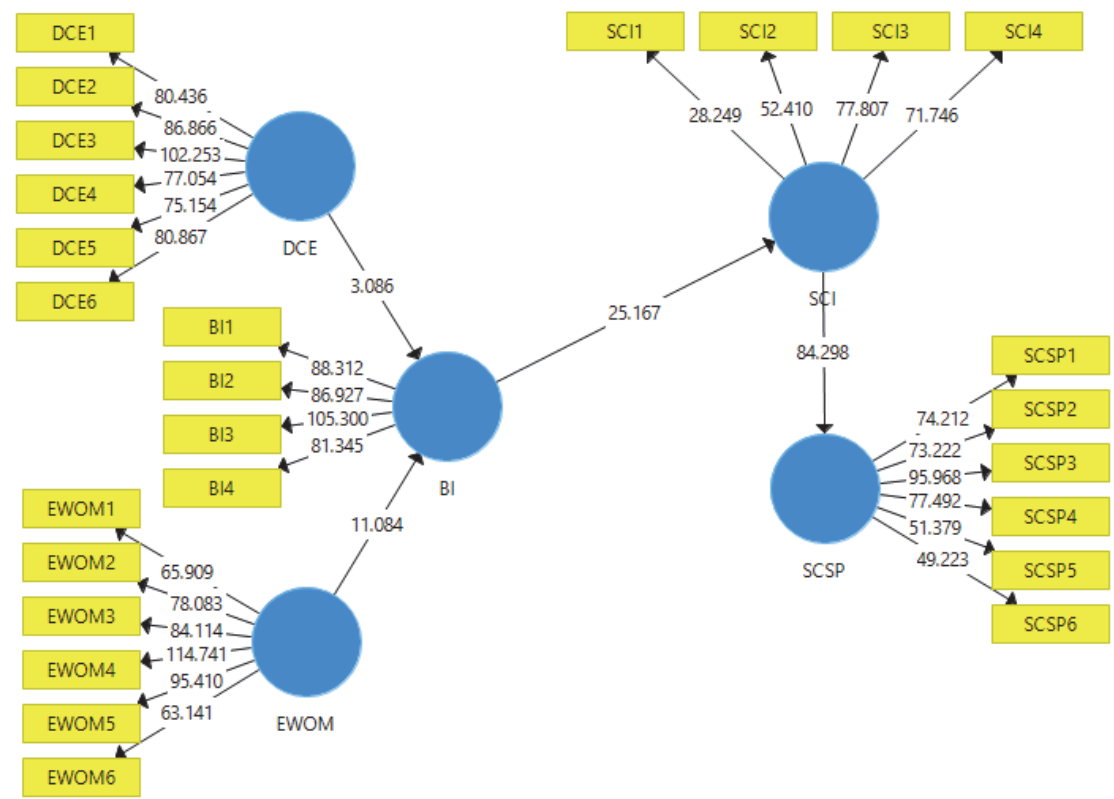

Fig. 3. Structural Model Assessment

Moreover, variance explained for sustainable supply chain performance is 0.823 which is shown in Fig. 2. It indicates that all the variances are explaining $82.3 \%$ variance in sustainable supply chain performance. Table 7 shows the quality of model with the help of predictive relevance $\left(\mathrm{Q}^{2}\right)$. It must be above zero to achieve the quality of model (Chin, 1998). Fig. 4 also shows the predictive relevance $\left(Q^{2}\right)$.

\section{Table 7}

Predictive Relevance $\left(\mathrm{Q}^{2}\right)$

\begin{tabular}{llll}
\hline & SSO & SSE & $\mathrm{Q}^{2}(=1-\mathrm{SSE} / \mathrm{SSO})$ \\
\hline BI & 888 & 267.004 & 0.699 \\
SCI & 888 & 545.96 & 0.385 \\
SCSP & $1,332.00$ & 499.763 & 0.625 \\
\hline
\end{tabular}

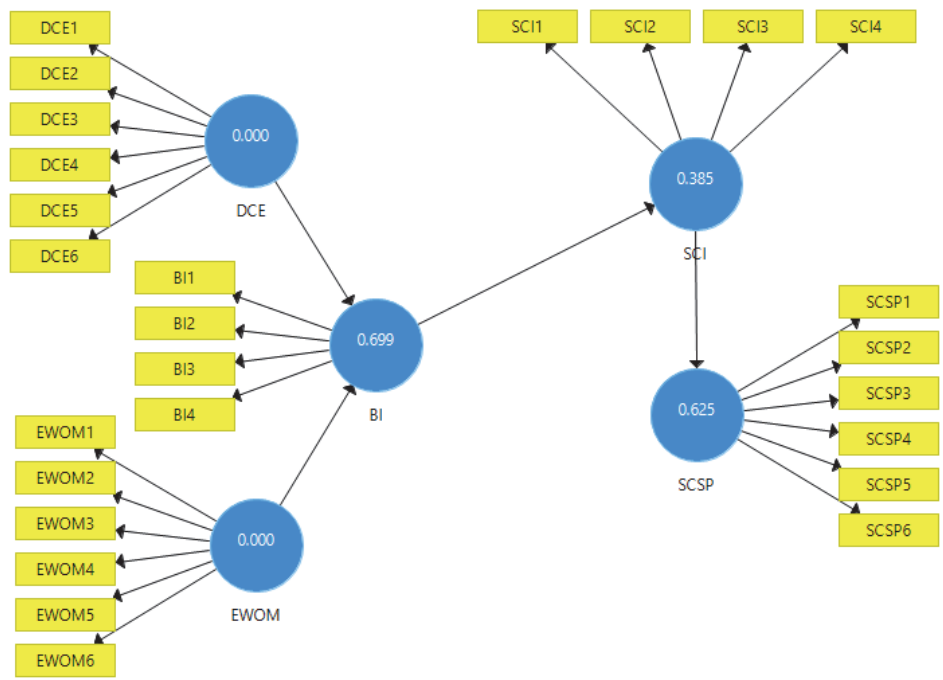

Fig. 4. Predictive Relevance $\left(Q^{2}\right)$ 


\section{Discussion and Conclusion}

The purpose of this study was to explore the effect of digital customer experience and electronic word of mouth on the performance of sustainable supply chain through brand image and supply chain image. Findings of the analysis show that digital customer experience and electronic word of mouth played positive role on promoting brand image. Digital customer experience through e-commerce and electronic word of mouth played positive role to boost brand image, brad image had positive role to boost supply chain image and finally promoted the performance of the sustainable supply chain.

The relationship between digital customer experience and electronic word of mouth had significant positive effect on brad image with t-value of 3.086 and 11.084, respectively. Increase in digital customer experience and electronic word of mouth promoted brand image. Both digital customer experience and electronic word of mouth were heavily based on e-commerce. As it is found by various studies branding and e-commerce had link with each other (Lowry et al., 2008; Penttinen \& Turunen, 2017). Therefore, e-commerce has pivotal role in digital customer experience and electronic word of mouth to promote brand image.

In line with the above findings, it has found that brand image had positive significant effect on supply chain image with t-value 25.167. Good brand image facilitates better supply chain image. As the brandings has relationship with supply chain image (Czinkota et al., 2014; Farquhar, 1994; Tsou et al., 2009; Zhang et al., 2013). Moreover, it is found that supply chain image increases the sustainable business performance. A significant positive relationship was found between supply chain image and sustainable business performance with t-value 84.298. Therefore, the combination of digital customer experience and electronic word of mouth increases supply chain sustainable performance through brand image and supply chain image in Indonesian ICT companies. Hence, Indonesian ICT companies should work to increase the brand image with the help of digital customer experience and electronic word of mouth which requires the implementation of e-commerce practices. Promotion of brand image has the ability to promote supply chain which automatically increases the overall performance.

\section{References}

Attaran, M., \& Attaran, S. (2007). Collaborative supply chain management: the most promising practice for building efficient and sustainable supply chains. Business Process Management Journal, 13(3), 390-404.

Baron, R. M., \& Kenny, D. A. (1986). The moderator-mediator variable distinction in social psychological research: Conceptual, strategic, and statistical considerations. Journal of Personality and Social Psychology, 51(6), 1173.

Betzing, J. H., Beverungen, D., \& Becker, J. (2018). Design principles for co-creating digital customer experience in high street retail. Proceedings of the Multikonferenz Wirtschaftsinformatik, MKWI'18.

Bilgihan, A. (2016). Gen Y customer loyalty in online shopping: An integrated model of trust, user experience and branding. Computers in Human Behavior, 61, 103-113.

Bolton, R. N., McColl-Kennedy, J. R., Cheung, L., Gallan, A., Orsingher, C., Witell, L., \& Zaki, M. (2018). Customer experience challenges: bringing together digital, physical and social realms. Journal of Service Management, 29(5), 776-808.

Brun, A., \& Castelli, C. (2008). Supply chain strategy in the fashion industry: developing a portfolio model depending on product, retail channel and brand. International Journal of Production Economics, 116(2), 169-181.

Castorena, O. H., Enríquez, L. A., \& Adame, M. G. (2014). The influence of information technology and communication supply chain management performance for greater SME manufacturing in aguascalientes. International Journal of Business, Economics and Management, 1(12), 382-396.

Chaudhuri, S., \& Mukhopadhyay, U. (2014). Foreign direct investment in developing countries. Springer.

Che, G. N., \& Sundjo, F. (2018). Determinants of female labour force participation in Cameroon. International Journal of Applied Economics, Finance and Accounting, 3(2), 88-103. 
Cheng, C. P., Phung, M. T., Hsiao, C. L., Shen, D. B., \& Chen, B. S. (2018). Impact of operational risk toward the efficiency of banking-Evidence from Taiwans banking industry. Asian Economic and Financial Review, 8(6), 815-831.

Chin, W. W. (1998). The partial least squares approach to structural equation modeling. Modern Methods for Business Research, 295(2), 295-336.

Chowdhury, T. S., Habibullah, M., \& Nahar, N. (2018). Risk and return analysis of closed-end mutual fund in Bangladesh. Journal of Accounting, Business and Finance Research, 3(2), 83-92.

Czinkota, M., Kaufmann, H. R., \& Basile, G. (2014). The relationship between legitimacy, reputation, sustainability and branding for companies and their supply chains. Industrial Marketing Management, 43(1), 91-101.

Das, K., Gryseels, M., Sudhir, P., \& Tan, K. T. (2016). Unlocking Indonesia's digital opportunity. (September), 1-28, Mc Kinsey Indonesia Report

Davis, C. H., \& Vladica, F. (2005). Micro-enterprises' Use of Internet Technologies and e-Business Solutions: a Structural Model of Sources of Business Value. Retrieved from

De Brito, M. P., Carbone, V., \& Blanquart, C. M. (2008). Towards a sustainable fashion retail supply chain in Europe: Organisation and performance. International Journal of Production Economics, 114(2), 534-553.

Dellarocas, C. (2003). The digitization of word of mouth: Promise and challenges of online feedback mechanisms. Management Science, 49(10), 1407-1424.

Dim, N. U., \& Ezeabasili, A. C. C. (2015). Strategic supply chain framework as an effective approach to procurement of public construction projects in Nigeria. International Journal of Management and Sustainability, 4(7), 163-172.

Duan, W., Gu, B., \& Whinston, A. B. (2008). Do online reviews matter?-An empirical investigation of panel data. Decision Support Systems, 45(4), 1007-1016.

Duru, P. N., \& Chibo, C. N. (2014). Flooding in Imo State Nigeria: The socio-economic implication for sustainable development. Humanities and Social Sciences Letters, 2(3), 129-140.

Farquhar, P. H. (1994). Strategic challenges for branding. Marketing Management, 3(2), 8.

Galant, V., Jakubczyc, J. A., \& Paprzycki, M. (2002). Infrastructure for E-commerce. Prace naukoweakademii ekonomicznej imienia oskara langego we wroclawiu, 931, 32-47.

Gebrina, A. (2009). The Relationship Between Brand Images and E-Commerce Practice on Firm Performance in Indonesia. Universiti Utara Malaysia.

Golicic, S. L., \& Smith, C. D. (2013). A meta-analysis of environmentally sustainable supply chain management practices and firm performance. Journal of Supply Chain Management, 49(2), 78-95.

Ha, H.-Y. (2002). The effects of consumer risk perception on pre-purchase information in online auctions: Brand, word-of-mouth, and customized information. Journal of Computer-Mediated Communication, 8(1), JCMC813.

Hair Jr, J. F., Hult, G. T. M., Ringle, C., \& Sarstedt, M. (2016). A primer on partial least squares structural equation modeling (PLS-SEM). Sage Publications.

Hair, J., Hollingsworth, C. L., Randolph, A. B., \& Chong, A. Y. L. (2017). An updated and expanded assessment of PLS-SEM in information systems research. Industrial Management \& Data Systems, $117(3), 442-458$.

Hennig-Thurau, T., Gwinner, K. P., Walsh, G., \& Gremler, D. D. (2004). Electronic word-of-mouth via consumer-opinion platforms: what motivates consumers to articulate themselves on the internet? Journal of Interactive Marketing, 18(1), 38-52.

Henseler, J., Ringle, C. M., \& Sinkovics, R. R. (2009). The use of partial least squares path modeling in international marketing New challenges to international marketing (pp. 277-319), Emerald Group Publishing Limited.

Imran, M., Hameed, W., U1, \& Haque, A., UL, . (2018). Influence of industry 4.0 on the production and service sectors in Pakistan: Evidence from textile and logistics industries. Social Sciences, 7(12), 246.

Joshi, A. (2018). Digital technologies for enhancing customer experience. Sansmaran Research Journal, 1-8. 
Kim, D., \& Cavusgil, E. (2009). The impact of supply chain integration on brand equity. Journal of Business \& Industrial Marketing, 24(7), 496-505.

Kimengsi, J. N., \& Gwan, S. A. (2017). Reflections on decentralization, community empowerment and sustainable development in Cameroon. International Journal of Emerging Trends in Social Sciences, 1(2), 53-60.

Klaus, P. (2014). Towards practical relevance-Delivering superior firm performance through digital customer experience strategies. Journal of Direct, Data and Digital Marketing Practice, 15(4), 306316.

Krejcie, R. V., \& Morgan, D. W. (1970). Determining sample size for research activities. Educational and Psychological Measurement, 30(3), 607-610.

Leetaru, K. (2008). Mass book digitization: The deeper story of Google Books and the Open Content Alliance. First Monday, 13(10).

Litvin, S. W., Goldsmith, R. E., \& Pan, B. (2008). Electronic word-of-mouth in hospitality and tourism management. Tourism Management, 29(3), 458-468.

Lowry, P. B., Vance, A., Moody, G., Beckman, B., \& Read, A. (2008). Explaining and predicting the impact of branding alliances and web site quality on initial consumer trust of e-commerce web sites. Journal of Management Information Systems, 24(4), 199-224.

Männistö, L. (1999). Electronic Commerce in Asia. Retrieved from https://www.itu.int/ITUD/ict/papers/ecom/18Marweb.pdf

Merrilees, B. (2016). Interactive brand experience pathways to customer-brand engagement and value co-creation. Journal of Product \& Brand Management, 25(5), 402-408.

Mihardjo, L. W. W., Alamsjah, F., Elidjen, E., \& Sasmoko, S. (2018). The Role of Corporate Reputation \& Distinctive Organization Capability in Developing Business Model Innovation: Case study of Indonesian ICT Firms in Facing Indutry Resolution 4.0. Opcion, 86(86), 2190-2208.

Morgan-Thomas, A., \& Veloutsou, C. (2013). Beyond technology acceptance: Brand relationships and online brand experience. Journal of Business Research, 66(1), 21-27.

Nadeem, S., Alvi, A. K., \& Iqbal, J. (2018). Performance indicators of e-logistic system with mediating role of Information and Communication Technology (ICT). Journal of Applied Economics \& Business Research, 8(4).

Nauwelaerts, Y., \& Chakri, S. (2016). The role of e-commerce and m-commerce in the international strategy of fashion companies: A qualitative research in the Belgian fashion industry. Innovation, 2, 80-113.

Nazal, A. I. (2017). Financial tables reports gaps in Jordanian Islamic Banks. The Economics and Finance Letters, 4(2), 9-15.

Nguyen, X.-T. N. (2001). Shifting the paradigm in e-commerce: Move over inherently distinctive trademarks--The e-brand, i-brand and generic domain names ascending to power. American University Law Review, 50, 937.

Nze, I. C., Ogwude, I. C., Nnadi, K. U., \& Ibe, C. C. (2016). Modelling the relationship between demand for river port services and vessel supply costs: Empirical evidence from Nigeria. Global Journal of Social Sciences Studies, 2(3), 144-149.

Peng, J., Quan, J., Zhang, G., \& Dubinsky, A. J. (2016). Mediation effect of business process and supply chain management capabilities on the impact of IT on firm performance: Evidence from Chinese firms. International Journal of Information Management, 36(1), 89-96.

Penttinen, H., \& Turunen, T. (2017). E-Commerce and Its Role in Strengthening a Brand: Case Company $X$.

Phelps, J. E., Lewis, R., Mobilio, L., Perry, D., \& Raman, N. (2004). Viral marketing or electronic word-of-mouth advertising: Examining consumer responses and motivations to pass along email. Journal of Advertising Research, 44(4), 333-348.

Poirier, C. C., \& Bauer, M. J. (2000). E-supply chain: using the Internet to revolutionize your business: how market leaders focus their entire organization on driving value to customers. Berrett-Koehler Publishers. 
Pradhan, R. P., Mallik, G., \& Bagchi, T. P. (2018). Information communication technology (ICT) infrastructure and economic growth: A causality evinced by cross-country panel data. IIMB Management Review, 30(1), 91-103.

Purnama, C. (2014). Improved performance through empowerment of small industry. Journal of Social Economics Research, 1(4), 72-86.

Quarshie, A. M., Salmi, A., \& Leuschner, R. (2016). Sustainability and corporate social responsibility in supply chains: The state of research in supply chain management and business ethics journals. Journal of Purchasing and Supply Management, 22(2), 82-97.

Reynolds, J., \& Mofazali, R. (2000). The complete e-commerce book: design, build, and maintain a successful web-based business. Cmp Books.

Richins, M. L., \& Root-Shaffer, T. (1988). The role of evolvement and opinion leadership in consumer word-of-mouth: An implicit model made explicit. ACR North American Advances.

Richter, K., \& Walther, J. (2016). Supply Chain Integration Challenges in Commercial Aerospace: A Comprehensive Perspective on the Aviation Value Chain. Springer.

Singh, R., \& Jayraman, V. (2013). Supply chain integration and information technology. International Journal of Economics Business and Management Studies, 2(2), 62-74.

Strebinger, A., \& Treiblmaier, H. (2006). The impact of business to consumer e-commerce on organizational structure, brand architecture, IT structure, and their interrelations. Schmalenbach Business Review, 58(1), 81-113.

Tanoos, J. J. (2017). East Asian trade cooperation versus US and EU protectionist trends and their association to Chinese steel exports. Asian Journal of Economics and Empirical Research, 4(1), 17.

Taqi, M., Ajmal, M \& Ansari, M.S (2018). Financial efficiency of India Tourism Development Corporation (ITDC) Limited: An empirical study. Journal of Tourism Management Research, 5(1), 14-22.

Tsou, C.-S., Fang, H.-H., Lo, H.-C., \& Huang, C.-H. (2009). A study of cooperative advertising in a manufacturer-retailer supply chain. International Journal of Information and Management Sciences, 20(1), 15-26.

Vendrell-Herrero, F., Bustinza, O. F., Parry, G., \& Georgantzis, N. (2017). Servitization, digitization and supply chain interdependency. Industrial Marketing Management, 60, 69-81.

Wang, Y. B., \& Lu, J. R. (2016). A supply-lock competitive market for investable products. Asian Development Policy Review, 4(4), 127-133.

Xue, L., Zhang, C., Ling, H., \& Zhao, X. (2013). Risk mitigation in supply chain digitization: System modularity and information technology governance. Journal of Management Information Systems, $30(1), 325-352$.

Zhang, J., Gou, Q., Liang, L., \& He, X. (2013). Ingredient branding strategies in an assembly supply chain: models and analysis. International Journal of Production Research, 51(23-24), 6923-6949.

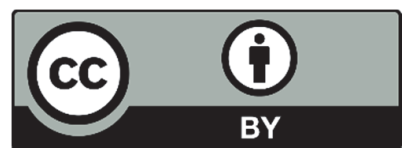

(C) 2019 by the authors; licensee Growing Science, Canada. This is an open access article distributed under the terms and conditions of the Creative Commons Attribution (CC-BY) license (http://creativecommons.org/licenses/by/4.0/). 